\title{
ВЛИЯНИЕ ПИЩЕВЫХ ЖИДКОСТЕЙ НА ОРГАНИЗМ И ЗУБОЧЕЛЮСТНУЮ СИСТЕМУ
}

\section{THE INFLUENCE OF FOOD FLUIDS ON THE BODY AND THE DENTITION}

\section{K. Abakeliya \\ T. Kosyreva}

Summary. The article is devoted to the problem of the influence of food fluids on the human body and dental system. Systematic consumption of food beverages, which are characterized by a low $\mathrm{pH}$, leads to hypersensitivity, erosion, and pathological tooth erasability. The article presents the results of a study of the effect of various food liquids on the microhardness of molars of teeth, which was carried out on experimental animals (rats). The results and conclusions are supported by the results of other clinical trials that show the effect of food beverages on hard dental tissues. It is concluded that food drinks cause damage to both healthy and affected teeth, aggravate the erosive process and carious course. The use of water does not lead to negative effects on the hard tissues of the tooth and the condition of fillings.

Keywords: food liquids, carbonated drinks, non-carious lesions of teeth, tooth enamel.

\author{
Абакелия Кама Гурелиевна \\ Аспирант, Российский университет дружбы народов \\ kamaabakeliya@mail.ru \\ Косырева Тамара Федоровна \\ Д.м.н., професссор, Российский университет дружбы \\ народов
}

Аннотация. Статья посвящена проблеме влияния пищевых жидкостей на организм и зубочелюстную систему человека. Систематическое употребление пищевых напитков, для которых характерно низкое рН, приводит к гиперчувствительности, эрозии, патологической стираемости зубов. Представлены результаты исследования воздействия употребления различных пищевых жидкостей на микротвердость моляров зубов, которое проводилось на экспериментальных животных (крысах). Полученные результаты и выводы обоснованы результатами других клинических испытаний, в которых показано влияние пищевых напитков на твердые ткани зубов. Сделан вывод 0 том, что пищевые напитки вызывают повреждение как здоровых, так и пораженных зубов, усугубляют эрозивный процесс и кариозное течение. Употребление воды не приводит к отрицательным эффектам на твердые ткани зуба и состояние пломб.

Ключевые слова: пищевые жидкости, газированные напитки, некариозные поражения зубов, зубная эмаль.

Следует отметить, что употребление газированных напитков, фруктов, соков, особенно свежевыжатых соков, является основной экзогенной причиной, приводящей к возникновению эрозивных повреждений твердых тканей зуба. В процессе контакта с зубом эти пищевые напитки приводят к снижению уровня рН до критического значения 5,5 и ведут к деминерализации эмали. На начальных стадиях эрозивный износ зуба проявляется в потере физиологического блеска эмалевой поверхности, на поздних стадиях происходят изменения в оригинальной морфологии зуба. При частом употреблении пищевых напитков с низкой $\mathrm{pH}$ на вестибулярной поверхности передних зубов появляются вогнутости, ширина которых явно превышает глубину [7].

Один из главных факторов, влияющих на разрушение зубов при употреблении газированных пищевых жидкостей, является кислотность питательных веществ, углекислый газ лишь немного повышает кислотность газированных напитков. Следовательно, газирование оказывает минимальное воздействие на процесс разрушения эмали и появление кариеса. Ведущую роль, определяющую повреждение зубов, играют такие факторы, как употребление кислотопродуцирующих про- 


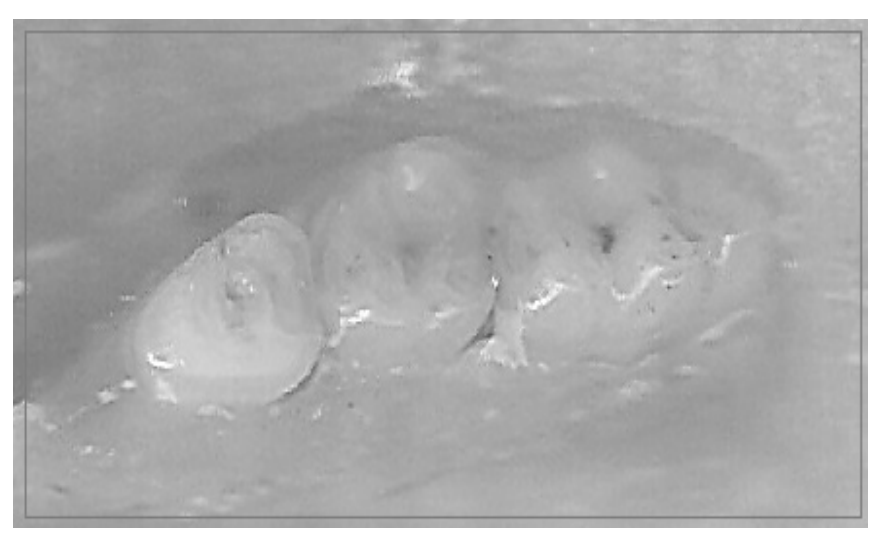

Образец из группы 1 (контрольной) в блоке из Протакрила

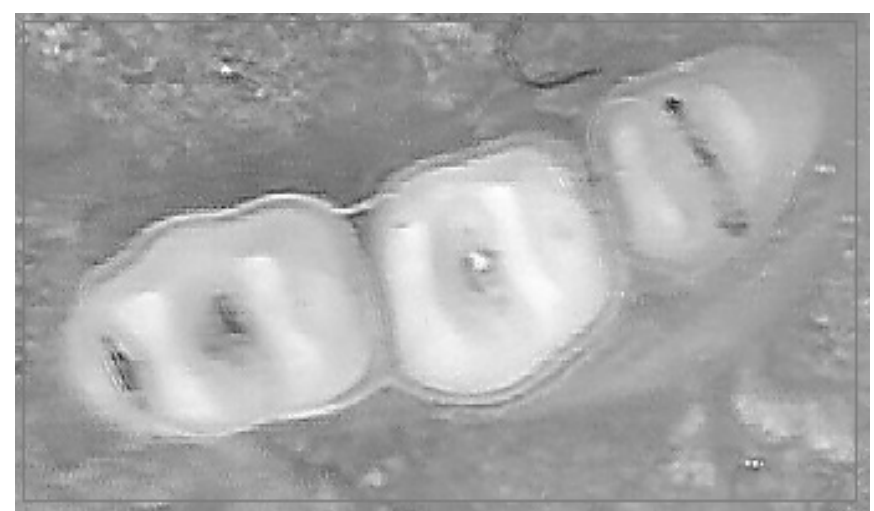

Образец из группы 4 в блоке из Протакрила. (образец, после шлифования и испытания на микротвердость)

Рис. 1. Фото процесса определения микротвердости (Hv) моляров зубов крыс

дуктов, дополнительных ингредиентов напитка и изменение слюны [10]. Сдвиг рН ротовой полости в кислую сторону оказывает влияние на активность ферментов слюны, процессы минерализации и реминерализации эмали, микроциркуляцию, активность микрофлоры, специфическую и неспецифическую резистентность тканей полости рта [4]. Деминерализация эмали зубов, возникающая в результате воздействия кислотных факторов пищевых напитков в полости рта, является начальным этапом кариозного процесса. Полноценная минерализация обусловливает большую устойчивость эмали зуба к кислотам, а недостаточная минерализация создает условия для возникновения кариозного процесса [3]. Другим фактором, оказывающим негативное влияние употребления пищевых жидкостей на организм человека, является входящие в их состав пищевые красители и добавки. Медико-биологические исследования, которые проводятся во многих странах мира, показывают связь заболеваемости с применением пищевых добавок. Среди последствий употребления пищевых красителей, содержащихся в пищевых напитках, можно выделить, не только влияние на зубы, но и развитие синдрома дефицита внимания и гиперактивности у детей, аллергии и приступы астмы, развитие онкологических заболеваний, врожденные дефекты [5].

Целью настоящего исследования, которое проводилось на экспериментальных животных (крысах), стало выявление негативного воздействия употребления различных пищевых жидкостей на микротвердость (Hv) моляров зубов.

\section{Организашия и метомы исслеАования}

Исследование проводилось в течение 3 месяцев. Были сформированы контрольная группа крыс (КГ) -
1 группа, которые получали водопроводную воду, и 4 экспериментальные группы (ЭГ), которые употребляли различные напитки: 2 группа - Coca-cola; 3 группа - медовая вода; 4 группа - дистиллированная вода; 5 группа - лёгкая вода.

Определение микротвердости (Hv) моляров зубов проводили на жевательных зубах фрагментов челюсти крыс после расчленения челюсти на левую и правую, удаления резцов и мягких тканей с последующей заливкой фрагментов группы жевательных зубов в блоки самотвердеющей пластмассы (Акродент или Протакрил) (рис. 1).

Определение показателя микротвердости проводили на микротвердомере Duramin-20 («Struers», Дания) по методу отпечатка по Виккерсу в единицах Hv (при нагрузке 50-100 г и времени выдержки под нагрузкой 10-30с). Применялась следующая формула:

$$
H v=0,1891 * F / d^{2}
$$

где $\mathrm{Hv}$ - значение микротвердости по Виккерсу; F нагрузка на испытуемую поверхность, $(\mathrm{H}) ; \mathrm{d}-$ средняя длина диагонали отпечатка индентора (мм).

\section{Результаты исслеАования}

Проведен сравнительный анализ средних показателей микротвердости эмали и дентина жевательных зубов крыс в зависимости от видов питья, которое получали экспериментальные животные в течение 3 месяцев (Рис. 1).

Результаты испытаний позволили сделать следующие выводы. В отличие от КГ крыс и группы эксперимен- 


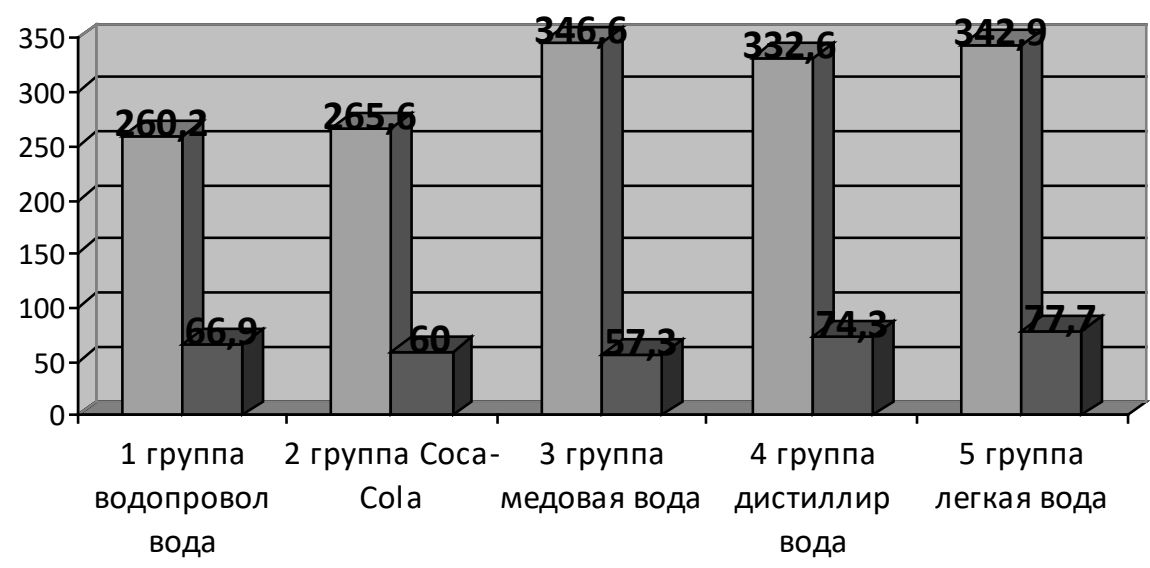

\section{Эмаль $\square$ Дентин}

Рис. 2. Показатели микротвердости эмали и дентина жевательных зубов крыс в зависимости от видов питья

тальных животных, употреблявших напиток Coca-cola, в группе крыс, употреблявших питье медовой, дистиллированной и лёгкой воды, выявлено достоверное повышение микротвердости эмали и дентина (с вероятностью $\mathrm{p}=0,000004-0,004$ эмали, $\mathrm{p}=0,0087-0,02$ дентина). Употребление дистиллированной воды повысило микротвердость эмали на 27,8\%; дентина - на 11,1\%; употребление лёгкой воды повысило микротвердость эмали на 31,8\%, дентина — на 16,1\%.

Полученные в ходе клинических испытаний выводы на экспериментальных животных подтверждают аналогичные клинические испытания, проведенные на людях, в ходе которых клинически доказано негативное воздействие употребления пищевых жидкостей на зубную эмаль. И.В. Фирсовой и соавт. в ходе клинических проб определялись закономерности между определенным напитком и глубиной окрашивания эмали в области границы «пломба-зуб», что отражало нарушение краевого прилегания; окрашивание эмали неотпрепарированных зубов указывало на деминерализацию твердых тканей. Результаты показали, что наиболее агрессивным из исследуемых газированных напитков является «СосаCola», при употреблении которого во всех случаях было выявлено яркое окрашивание зубной эмали красителем, вследствие ее деминерализации. Микроподтекание по границе «пломба - зуб», указывающее на нарушение герметизма пломб, было обнаружено в каждом втором случае [6]. Микроскопическое исследование среза после воздействия напитка Coca-cola, проведенное Э. В. Басиевой, О.Э. Рамоновой, показало глубокую пигментацию эмали красителем, входящим в состав напитка, расширение дентино-эмалевой границы, сужение просвета дентинных канальцев, облитерацию дентинных каналь- цев кристаллами гидроксиаппатитов [1]. Употребление энергетика также приводит к яркому окрашиванию эмали красителем во всех случаях, а микроподтекание пломб только в каждом десятом случае. В отличие от газированных напитков, употребление минеральной воды «BonAqua» не выявило отрицательного влияния на твердые ткани зуба и состояние пломб [6]. Другое исследование было направлено на анализ влияния газированных напитков, содержащих пищевые красители, на твердые ткани зуба и светоотверждаемые пломбировочные материалы, поскольку правильный выбор пломбировочных материалов позволяет сохранить внешний вид пломб с учетом употребляемых пациентом красящих пищевых напитков. В ходе исследования были выбраны такие газированные напитки, как «Тархун» и «Байкал», которые отличаются по составу красящих веществ. В качестве контрольного напитка выступала газированная вода «Ессентуки». Результаты исследования также показали негативное воздействие красящих веществ, входящих в состав исследуемых газированных напитков, на пломбировочный материал [2].

Проведены исследования, направленные на выявление влияния на твердые ткани зубов пищевых напитков Coca-Cola, энергетик Burn, чай Nestle, натуральный сок J7, кофе Moccona. Результаты исследования показали, что данные пищевые напитки вызывают повреждение как здоровых, так и пораженных зубов, вызывая усугубление кариозного течения. Химический состав пищевых напитков способствует растворению твердых тканей зуба, вызывая эрозивный процесс, сахар и лимонная кислота приводят к деминерализации эмали, вызывая в последующем кариес, а краситель глубоко окрашивает зуб [1]. 
Аналогичные клинические испытания проведены и зарубежными исследователями. Большинство зарубежных исследований посвящены вопросам деминерализации и реминерализации, которые проводились с использованием метода атомно-силовой микроскопии. Так, согласно результатам, полученным E. Quartarone et. al., было выявлено образование глубоких отверстий в структуре эмали под действием кислых напитков [9]. Влияние деминерализации под действием кислого безалкагольного напитка было исследовано B.-D. Lechner et al. [8].
Таким образом, полученные результаты и выводы показывают, что при систематическом употреблении кислотосодержащих пищевых напитков неизбежны негативные влияния на зубочелюстную систему организма человека, которые ведут к таким негативным последствиям, как нарушения твердых тканей зубов и развитие кариеса. Результаты исследования обосновывают профилактические рекомендации для пациентов, согласно которым необходимо исключить употребление кислотосодержащих пищевых напитков в целях предупреждения некариозных и кариозных поражений твердых тканей зубов.

\section{ЛИТЕРАТУРА}

1. Басиева Э. В. Влияние различных напитков на состояние твердых тканей зубов / Э. В. Басиева, О. Э. Рамонова // Медико-фармацевтический журнал «Пульс».— 2015. — № 1 (17).— С. 35-36.

2. Белявская А. А. Влияние газированных напитков на пломбировочные материалы и твердые ткани зуба / А. А. Белявская, С. П. Деревянченко // Здоровье и образование в XXІвеке.-2015.- № 4 (17) - С. 333-334.

3. Боровский Е. В. Кариесрезистентность / Е. В. Боровский, В. К. Леонтьев //Стоматология.— 2002.— № 5. - С. $26-28$.

4. Галиуллин А. Н. Влияние медико-социальных факторов на развитие кариеса зубов у детей / А. Н. Галиуллин, Е. А. Россейкина, Р. Г. Бурганов // Казанский медицинский журн. - 2002. - № 1. -С. 58-59.

5. Нечаев А. П. Пищевая химия / А. П. Нечаев, С. Е. Траубенберг, А.А.

6. Кочеткова.—Санкт-Петербург: ГИОРД, 2003.-640 с

7. Фирсова И. В. Влияние газированных и алкогольных напитков на зубы / И. В. Фирсова, Ю. А. Македонова, Р.С. Камалетдинова, Е. В. Кобелев // Медико-фармацевтический журнал «Пульс».— 2014. — № 3 (16).— —. 12-14.

8. Юдина Н. А. Эрозия зубов: терминология, диагностика, профилактика и лечение // Современная стоматология.— 2015.— № 1.— С. 8-13.

9. Lombardini. Surface kinetic roughening caused by dental erosion: an atomic force microscopy study / E. Quartarone [et al.] // Journal of Applied Physics. — 2008. — Vol. 103, № 10. - P. 104702.

10. Monitoring demineralization and subsequent remineralization of human teeth at the dentin-enamel junction with atomic force microscopy / B.-D. Lechner [et al.] // ACS Applied Materials Interfaces. — 2015. — № 7(34).— P. 18937-18943.

11. Prabhakar AR, Kurthukoti AJ, Gupta P. Cariogenicity and acidogenicity of human milk, plain and sweetened bovine milk: an in vitro study // Clin Pediatr Dent. 2010, Spring. — № 34 (3). - P. 239-247.

๑ Абакелия Кама Гурелиевна ( kamaabakeliya@mail.ru ), Косырева Тамара Федоровна.

Журнал «Современная наука: актуальные проблемы теории и практики» 